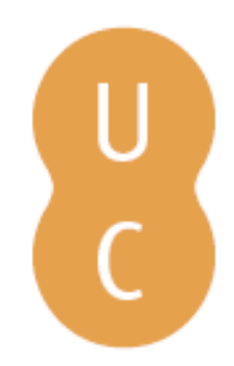

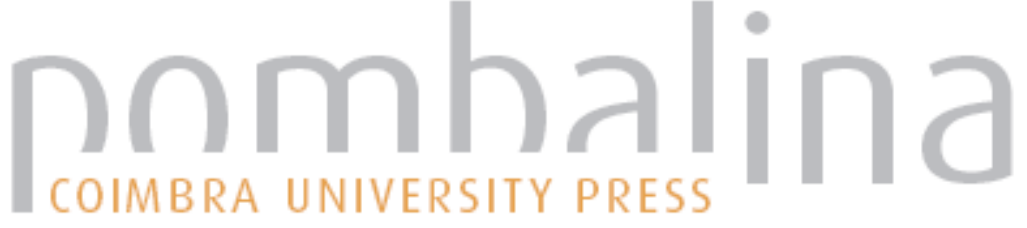

Mário de Carvalho e a reflexão metaficcional sobre o futuro do romance

Autor(es): $\quad$ Martins, José Cândido de Oliveira

Publicado por: Imprensa da Universidade de Coimbra

URL

persistente:

URI:http://hdl.handle.net/10316.2/37023

DOI:

DOI:http://dx.doi.org/10.14195/978-989-26-0548-7_3

Accessed : $\quad$ 26-Apr-2023 10:48:26

A navegação consulta e descarregamento dos títulos inseridos nas Bibliotecas Digitais UC Digitalis, UC Pombalina e UC Impactum, pressupõem a aceitação plena e sem reservas dos Termos e Condições de Uso destas Bibliotecas Digitais, disponíveis em https://digitalis.uc.pt/pt-pt/termos.

Conforme exposto nos referidos Termos e Condições de Uso, o descarregamento de títulos de acesso restrito requer uma licença válida de autorização devendo o utilizador aceder ao(s) documento(s) a partir de um endereço de IP da instituição detentora da supramencionada licença.

Ao utilizador é apenas permitido o descarregamento para uso pessoal, pelo que o emprego do(s) título(s) descarregado(s) para outro fim, designadamente comercial, carece de autorização do respetivo autor ou editor da obra.

Na medida em que todas as obras da UC Digitalis se encontram protegidas pelo Código do Direito de Autor e Direitos Conexos e demais legislação aplicável, toda a cópia, parcial ou total, deste documento, nos casos em que é legalmente admitida, deverá conter ou fazer-se acompanhar por este aviso. 
do Tempo e da História

- Mário de Carvalho e a reflexáo metaficcional sobre o futuro do romance - Sátiva e o cepticismo: configuração de personagens em Mário de Carvalho - Escrever tem arte e tem segredos... Era bom que trocássemos umas ideias sobre o assunto - O processo criativo em Era bom que trocássemos umas ideias sobre o assunto - Intertextualidade e metaficção em Fantasia para dois Coronéis e uma Piscina, de Mário de Carvalho - Trimalquiāo, os coronéis e a piscina: retrato impiedoso de um pais em crise $\bullet A$ Paixão do Conde de Fróis: paródia e subversão • "Como dizia o outro": a presença dos Clássicos em Mário de Carvalho - Cultura Clássica em Um

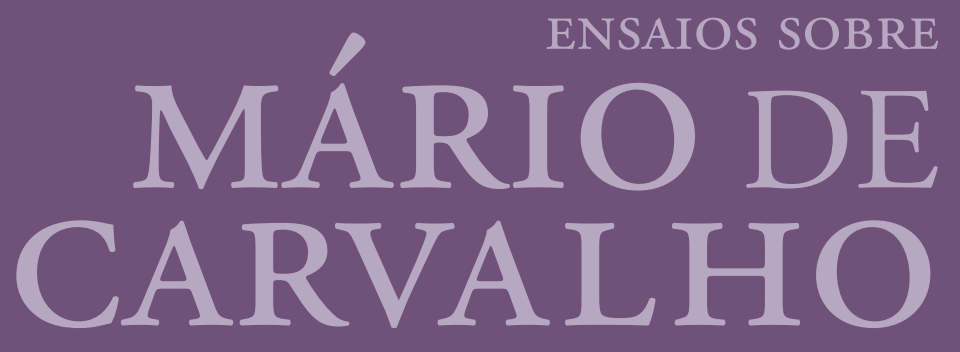

Maria de Fátima Silva Tereza Virgínia Ribeiro Barbosa COORD. IMPRENSA DA UNIVERSIDADE DE COIMBRA COIMBRA UNIVERSITY PRESS

elemento mouro como simbolo de alteridade $e$ barbárie em Um deus passeando pela brisa da 


\section{Mário de Carvalho e a reflexáo metaficcional sobre o futuro do romance}

José Cândido de Oliveira Martins

Universidade Católica Portuguesa 
(Página deixada propositadamente em branco) 


\section{Rumos de uma cartografia possível}

É compreensivelmente complexa qualquer tentativa de cartografar as principais tendências do romance ou da ficção portuguesa contemporânea. Para contrariar ou moderar esta ousadia, é frequente argumentar-se com a falta de distanciamento crítico suficiente; mas ainda com a multiplicidade de orientaçóes estéticas e de percursos singulares de escrita dos autores atuais no campo da narrativa.

Contudo, estas e outras razóes não nos devem inibir de esboçar - aqui assumidamente muito de relance e a pretexto do percurso de Mário de Carvalho (Lisboa, 1944) - um sucinto mapeamento de algumas dessas tendências da escrita ficcional. Para além dessa ressalva, impóe-se outra também de natureza metodológica, embora sem exagerado rigor demarcativo - a ficçáo contemporânea de que falamos estende-se grosso modo entre duas balizas cronológicas: a revolução de abril de 1974 e a atualidade, após a superação do século e do milénio, tendo já suscitado alguns diferenciados balanços críticos (cf. Arnaut 2002; Reis 2005).

Ora, nestas últimas décadas, ainda bem próximas de nós leitores e críticos - e sem pretensôes de nenhum tipo de revisão abarcante ou exaustiva -, é possível rastrearem-se várias tendências encetadas ou aprofundadas pela ficção portuguesa contemporânea, com destaque para alguns traços ou caminhos que, por diversas razões, também não são alheios à natureza e orientaçôes da poética ficcional de Mário de Carvalho e, concretamente, ao delimitado tópico que nos interessa de momento:

i) A revitalização da História, em registos bastante diferenciados, desde a evocação mais respeitadora, "ortodoxa" e algo epigonal (revivescência do romance histórico tradicional), até à reinterpretação alegóri$\mathrm{ca}$, revisionista e parodicamente desmitificadora, tal como analisado criticamente por Maria de Fátima Marinho (2010), quando reflete sobre o tópico da identidade perdida.

ii) Correlacionadamente, a questionação de uma certa ideia de "identidade nacional", particularmente da problematização do imaginário nacional e do ontológico "modo de ser português", sem esquecer o papel de certas narrativas fundadoras ou identitárias, de acordo com conhecida tese de Eduardo Lourenço (1982).

iii) A tendência acentuadamente pós-moderna para a autorreflexão metaficcional, em que a escrita reflete sobre si mesma, sobre os seus processos e convençóes, afastando-se, de modo crítico, de certo 
paradigma clássico de escrita ficcional (com destaque para a problematização do género romanesco, sua poética e fronteiras com outros géneros) - metafiç̧ão no sentido genérico de narrativa cujas variadas manifestaçóes de autorreflexividade a tornam consciente do seu próprio processo narrativo, quer a nível diegético, quer linguístico, em modalidades de maior ou menor visibilidade, metaficção manifesta ou dissimulada (cf. Hutcheon 1984: 23 e 31). Este é o ponto que nos interessa focar seguidamente.

iv) A construção de discursos literários de índole assumidamente intertextual e interdiscursiva, através da incorporação de outros textos, discursos e géneros, numa atitude por vezes lúdica, num "palimpsesto saturado" no caso de Mário de Carvalho (cf. Silvestre 1998: 213). Essa densidade intertextual (urdida de citações disfarçadas, referências, alusōes, montagens, etc.) mostra-se um tecido naturalmente desafiadora da competência literária do leitor; ao mesmo tempo, é decisiva para a construção da pluralidade ou densidade dos sentidos textuais; e apresenta-se ainda contaminada por uma dose variável de humor, sobretudo ao convocar e aproximar autores, referências e saberes aparentemente díspares e em quantidade tâo notória.

v) Interligadamente, a assunção da paródia enquanto metadiscurso recorrente, apostado na inversão irónica de géneros e de textos, de códigos e de convençóes. Entendendo-se aqui paródia como um metadiscurso, intrinsecamente dialógico e imitativo, que opera sobretudo uma inversão irónica, com distanciamento crítico, de um outro discurso literário (sob a forma de texto, género, convenção ou código literários), cuja amplitude do ethos se estende ao cómico mais ou menos ridicularizador até à homenagem disfarçada ou respeitosa (cf. Rose 1979; Hutcheon 1985).

Estas e outras tendências marcantes da recente evolução do género romanesco demonstram a polivalência e a complexidade da escrita do romance, genologicamente recetivo às mais diversas transformaçóes; e, sobretudo, aberto a uma crescente autorreflexividade, que não exclui processos de autoironia e de autoparódia. Curiosamente, já na segunda metade do séc. Xx, na conhecida reação diante da obra de François Mauriac, o crítico Jean-Paul Sartre insistia na ideia de que era necessário superar o esgotado modelo clássico de romance; e Marthe Robert acrescentará que o único caminho era através da desmontagem irónica (cf. Raimond 1989: 25). Aliás, sabemos bem como a inovadora teoria literária dos formalistas russos 
(I. Tynianov, V. Chklovski ou B. Tomachevski) acentuou a funcionalidade reguladora da paródia ao nível das transformaçóes operadas no sistema literário.

Com efeito, no caso particular de que nos ocupamos, a ostensiva presença do narrador na ficção de Mário de Carvalho assume múltiplas formas e objetivos - da sátira sobre a sociedade contemporânea à visão estética sobre o próprio fazer literário. Enquanto forma aberta, tradicionalmente definida pelas ideias de totalização simbólica, singularidade e universalidade (cf. Lukács 1989), o romance do autor português apresenta-se assim como género em assumida mutação, de natureza não só evolutiva e de propósitos autocríticos; mas também como um género proteiforme, assumindo ou deixando-se contaminar por outros discursos e géneros, do ensaio à poesia, passando pela crónica. Curiosamente, é o próprio escritor a declarar que "o romance está em aberto" - como escreveu no Jornal de Letras em 2 de agosto e de 1995 -, no sentido em que, de facto, não possui uma poética coerciva e limitadora da evolução dos seus códigos compositivos. Por outras palavras, o romance contemporâneo, de autores como Mário de Carvalho, transporta uma matriz de inventividade e de autorregeneração, incompatível com qualquer ideia de uma poética fixa e intemporal.

Consabidamente, a partir da segunda metade do séc. $\mathrm{xx}$, os ficcionistas mostram-se muito mais conscientes de questóes teóricas implicadas no processo ficcional. Nesta tendência marcante para explicitar o fazer literário, avultam as manifestaçôes de frequente e obsidiante autorreflexividade. $\mathrm{Na}$ escrita de autores tão diversos como Jorge Luís Borges, Vladimir Nabokov, John Barth, Ítalo Calvino ou Umberto Eco, mas também José Saramago ou Mário de Carvalho - para só citarmos alguns ficcionistas -, desenvolve-se uma continuada e renovadora teoria da ficção a partir da prática da ficção, numa permanente tensão entre sistema (langue) e prática literária (parole), à luz duma perspetiva semiótica de matriz saussureana: "Each metafictional novel self-consciously sets its individual parole against the langue (the codes and conventions) of novel tradition" (Waugh 2003: 2).

Para o ponto que nos ocupa, mostra-se crucial uma aproximaçáo teórico-crítica entre pós-modernismo e metaficção, em que radica todo um programa ficcional de autorreflexão do género romanesco. Da referida Patricia Waugh, o conceito de metafiç̧ão é assim definido: "Metafiction is a term given to fictional writing which self-consciously and systematically draws attention to its status as an artefact in order to pose questions about the relationship between fiction and reality" (Waugh 2003: 11). Já outros estudiosos do pós-modernismo, como Linda Hutcheon (1989: 48), optam 
por, entre outras conceituaçóes, definir a narrativa metaficcional como "representation of writing as representation". Também o teórico inglês David Lodge, também ele autor de diversos romances metaficcionais, descreve a ficção pós-moderna através das manifestações de metaficção.

Esta propensão para reflexão metaficcional deve inserir-se numa postura crítico-filosófica bem mais ampla, de autoconsciência hermenêutica e cognoscitiva sobre o modo como o nosso conhecimento do mundo é mediado pela linguagem. Isso é particularmente visível em diversos meta-discursos que, a nível social e cultural, dentro e fora das ciências humanas, problematizam epistemologicamente as condiçóes e a natureza do conhecimento humano. Esta atitude inquiridora e até cética faz sentido num tempo de grande aceleração da História, de grandes mutações, mas também de enorme incerteza e instabilidade, onde tudo se questiona - das certezas científicas aos valores, das ideologias às religióes.

Similar preocupação reflexiva e problematizante se tem vindo a verificar latamente no domínio dos estudos literários - a obra literária como facto de linguagem, v.g. - e, em particular, na questão central da construção dos mundos ficcionais do género romanesco. $\mathrm{O}$ tradicional paradigma de romance realista (com suas técnicas narrativas, códigos estéticos, pressupostos ideológicos e respetiva mundividência), já não se adequa à nova realidade atual e aos valores culturais dominantes, como demonstrado aliás por sucessivas metamorfoses do romance moderno e contemporâneo, logo a partir das primeiras décadas do séc. Xx, desde M. Proust, J. Joyce ou F. Kafka, passando pelo nouveau roman francês, entre outras marcantes tendências renovadoras do género (cf. Albérès 1972).

Neste quadro, a orientação metaficcional desnuda o valor coercivo dos géneros e o peso das convençóes literárias tradicionais, acentuando a sua pretensa saturação ou esgotamento. Com esta postura, o sistema literário patenteia capacidades críticas de autorregulação, nomeadamente ao nível da escrita literária e da evolução de um género em particular, como o romance, debatendo-se aí as forças contraditórias de preservação e de rutura, da evolução do sistema e da sua manutenção e impositividade; ou seja, numa tensão entre a normatividade do sistema (código literário romanesco) e a pressão para um processo evolutivo do género. É neste âmbito que se deve entender a crescente consciência da dimensão de artifício das convençóes e dos processos romanescos e da necessidade da sua questionação e evolução.

Como se constata, o problema de fundo extravasa a teoria do romance ou da ficção, mas conhece aí particular acuidade. Trata-se da questáo 
central da representação, inerente ao processo literário e ficcional, enquanto construção assente na linguagem e no seu poder de efabulação. Afinal, numa perspectiva semiótico-comunicacional, a realidade (sistema social) e a linguagem (sistema linguístico) precedem o texto literário e romanesco, bem como os seus códigos (sistema literário). Está em causa, hoje talvez de uma forma mais intensa, a axial problematização das relaçôes entre as palavras e as coisas, variante moderna da velha dicotomia res/uerba; isto é, a capacidade de representação da realidade através da literatura e sobretudo do romance, como estudado crítica e diacronicamente por Erich Auerbach (1976), entre tantos outros estudiosos.

Concretizemos, como se interroga, implícita e metaficionalmente, a própria ficção de Mário de Carvalho: faz sentido que numa realidade contemporânea tão acelerada e mutável, com reflexos ao nível do sistema literário, o romance continue a usar as conceçóes de outrora? A crise das ideologias, das grandes narrativas e da cultura, como assinalado por reconhecidos ensaístas, acaba por ter reflexos nas ideias da impositividade de um cânone ou da autoridade coerciva poética de um género e respetivo arquitexto; e, desse modo, originando e contaminando, irremediavelmente, a própria ideia de crise e correspondente desejo de autorrenovação do romance, da sua natureza e dos seus limites.

Daí também deriva a constatação de o romance moderno e contemporâneo assumir muitas vezes a feição de anti-romance, implodindo, irónica e parodicamente, velhos paradigmas e processos; ao mesmo tempo que configura um padrão reflexivo de ficção sobre a ficção (metaficção), fenómeno vasto a que o ensaísta Carlos Ceia prefere chamar de ficcionismo (cf. Ceia 2007: 13, 121 e ss.).

\section{Mecânica da ficção: metaficção e paródia}

É um lugar-comum da teoria literária e da crítica atual reconhecer que o romance contemporâneo se pensa auto-reflexivamente, num permanente processo evolutivo. Contudo, apesar da relativa novidade do termo "metaficção" - e respetivo afấ teorizador -, a sua prática é quase tão antiga quanto a história do romance, desde Miguel de Cervantes e Laurence Sterne até romance modernista. Aliás, como sustentado por diversos teóricos e historiadores do romance, a atitude metaficcional mostra-se, em certo sentido, congenial ao romance enquanto género sem lei, isto é, sem uma poética clássica normativa, dotada de rigidez e impositividade dos 
seus códigos, à imagem de outros géneros. Como salientado por Patrícia Waugh (2003: 67), na própria natureza ou matriz do género romanesco e, consequentemente, na sua evolução história, está inscrita a tendência para a autorreflexão metalinguística e metaficcional:

The novel, always inherently self-conscious, always inherently provisional in its process relativizing language through continuous assimilation of discourses, has now and again to stop and examine the process, to see where it is going, to find out what it is.

Como sugerido, a essência do romance mostra-se incompreensível sem esta atitude auto-reflexa, até como forma crítica de contrariar a exaustão do género. É justamente neste âmbito da natureza mais livre do género romanesco que se compreende, ao longo da sua história, as relaçóes fecundas com outros géneros e formas, valorizando-se assim não só um contínuo processo de autoquestionamento, mas um modo peculiar de enriquecedoras relaçóes dialógicas. Por isso, o teorizador russo M. Bakhtine (1970; 1981: 39) insistiu tanto no dialogismo do romance, enquanto género dinamicamente aberto à relação com outros discursos e enunciados. Assim sendo, como espaço de interaçáo verbal e discursiva, não surpreende que o romance potencie uma reflexão metaficcional no contexto desta abertura dialógica; e esse procedimento se constitua como caminho de desconstrução de certo paradigma tradicional, ao mesmo tempo que procura caminhos de superação, como no que designou de romance polifónico.

É neste contexto problematizador, rapidamente introduzido, que devemos inserir a singular criação do ficcionista Mário de Carvalho, autor de várias obras dispersas por diversos géneros ficcionais, do conto à novela e ao romance, passando pelo teatro. Na sua produção romanesca - secundarizemos a narrativa curta, para o tema em análise -, manifestam-se algumas das tendências antes sugeridas, em maior ou menor grau, encontrando-se aí modulaçôes muito pessoais, de acordo com uma estilística e uma poética ficcional ímpares.

Como sugerido, destaca-se especialmente a natureza metaficcional das narrativas de Mário de Carvalho. Parafraseando o crítico James Wood (2010), atentemos então na maneira como funciona a mecânica da ficção de Mário de Carvalho (how fiction works); isto é, ilustremos a maneira como uma alargada e constante atitude metaficional perpassa de modo permanente a sua escrita, norteada náo apenas por propósitos lúdicos-verbais, mas sobretudo críticos e revisionistas, atitude valorizadora de uma certa 
maneira de conceber o "fazer literário". Por outras palavras, a escrita de Mário de Carvalho ostenta uma aguda autoconsciencialização do processo narrativo ao nível da própria urdidura ficcional. Volta-se reflexivamente para si própria, questionando os princípios da sua poética possível, através de uma assinalável variedade de procedimentos.

Com efeito, a leitura crítica de um selecionado corpus de Mário de Carvalho - Era bom que trocássemos umas ideias sobre o assunto (1995); Fantasia para dois coronéis e uma piscina (2003); e $A$ arte de morrer longe (2010), que naturalmente poderia ser mais alargado, mesmo temporalmente - permite-nos, por si só, indagar como o escritor desnuda alguns artifícios e convençóes do romance ou da ficçáo tradicional, numa postura assumidamente metaficcional e parodística, sem se perder numa postura de mero entretenimento ou jogo verbal.

Bem ao contrário, o escritor demonstra plena consciência de que, ao longo das últimas décadas, foram vários os ficcionistas que desmontaram, ironicamente e a vários níveis, uma certa tradição ou paradigma de "romance clássico", com os seus códigos de referência (da velha omnisciência narrativa à indagação psicológica, passando por determinada estruturação discursiva). Definitivamente, partindo da velha e proverbial afirmação de Paul Valéry - sublinhada pela poética surrealista de André Breton -, já não é mais possível escrever um romance em cujo incipit se declare, em detalhismo informativo: "A marquesa saiu às 5 horas"...

Ao mesmo tempo, diante de um espírito inconformado e renovador bem assumido, como é o de Mário de Carvalho, não é recomendável ler a sua ficção fora de uma inteligente cultura do humor, que se serve da ironia e da paródia metaficcionais para desmontar o esgotamento de certos processos. Numa conceção assumidamente lúdica da estrutura narrativa, densamente intertextual, as vozes narrativas controladoras destas três ficções de Mário de Carvalho desconstroem, de modo constante e paródico, a formalidade de certos protocolos de leitura ou convençóes narrativas. Neste sentido, a singularidade da escrita de Mário de Carvalho nestes romances confirma a tese de Carlos Ceia (2007: 220):

A paródia é a forma privilegiada do exercício poético-ficcional da autorreflexividade. (...) Não sendo um recurso exclusivo de uma época, está suficientemente documentada no espaço que se convencionou chamar literatura pós-moderna para nos permitir distinguir a paródia também como paradigma desta época. A condiçáo de autorreflexividade é apenas uma forma de realização da paródia e não a sua definição final (...). 
O tom estilístico da obra de Mário de Carvalho é logo dado pela inesperada e provocatória "Advertência" autoral, em epígrafe de Era bom que trocássemos umas ideias sobre o assunto, geradora de um humorado horizonte de expectativa: "Este livro contém particularidades irritantes para os mais acostumados. Ainda mais para os menos. Tem caricaturas. Humores. E alguns anacolutos" (Carvalho 1995: 9). Em outros livros de Mário de Carvalho, as epígrafes e os incipits cumprem função semelhante, investindo claramente no sentido destas inscriçóes peritextuais; e sobretudo estimulando provocatória e humoradamente o leitor inteligente, de modo a nunca o deixar indiferente. Simultaneamente, a notável destreza e o grande à vontade do autor no manejo da escrita e dos mecanismos de ficção está indiciado, ao nível da enunciação narrativa, em procedimentos como o referido. Porém, alarga-se a muitos outros, num jogo irónico e paródico constante, desafiando a sagacidade cúmplice de um leitor ativo.

Esta atitude lúdica e metaficcional demonstra-se especialmente numa diversificada quantidade de procedimentos. Revela-se, desde logo, na frustração do arranque da narrativa ou da sua linear organização discursiva (mais dada a analepses, elipses e sumários) - quando o leitor, mais preso a esquemas e modelos tradicionais, poderia esperar certo desenvolvimento convencional da diegese, é frequentemente surpreendido com outra estrutura ou com interrupções inesperadas. Satirizando certos cursos académicos de escrita criativa, o narrador náo hesita em desnudar o processo produtivo, argumentando que o relato não avança por causa da sua concessão às divagaçôes: "E porque já vamos na página dezoito, em atraso sobre o momento em que os teóricos da escrita criativa obrigam ao início da ação, vejo-me obrigado a deixar para depois estas desinteressantes e algo eruditas consideraçóes (...) (Carvalho 1985: 18).

$\mathrm{O}$ alargado programa metaficcional do escritor manifesta-se também nas conscientes descoincidências entre o tempo da diegese e o tempo do discurso: "Por um instante fugaz - tanto que leva mais tempo a contar que a acontecer - tentou recordar (...)" (Carvalho 1985: 27), refere autor-reflexivamente o narrador a propósito do pensamento evocativo de uma personagem; ou ainda na intromissáo inesperada de certas personagens, que irrompem em cena com motivaçóes mais ou menos credíveis. Com essa postura, desnudam-se processos cruciais como o da organização da diegese ao nível do discurso narrativo; ou ainda os códigos de ilusão romanesca que presidem à composição das dramatis personae.

A mesma atitude irónica e metaficcional é visível nos repetidos procedimentos de questionação da verosimilhança e dos seus processos; 
bem como da denúncia do abuso de certos "expedientes literários" (Carvalho 1995: 33), como o famigerado "deus ex machina"- de ascendência clássica e teatral, este expediente é abundantemente parodiado pela escrita ficcional de Mário de Carvalho (cf. 2003: 222; 2010: 44, 66), como tópico exemplar de outros artifícios da narrativa tradicional - gato escondido com o rabo de fora... Em A Arte de Morrer Longe, o narrador mostra-se ironicamente perentório: "Abaixo os expedientes para introduzir uma narração à conta dum adormecimento" (Carvalho 2010: 34). Aliquando bonus dormitat Homerus... A fluência da narrativa deve prescindir desses artifícios que já não enganam nenhum leitor, pois estáo gastos de tanto uso.

O afã metaficcional do escritor está patente também na reflexão expressa sobre o uso de certa opção ao nível focalização narrativa - "Um narrador omnisciente tem as suas vantagens" (Carvalho 1995: 35), assevera a voz narrativa de Era bom que trocássemos umas ideias sobre o assunto; ou na surpresa do narrador ao ver-se surpreendido com as falas que uma das suas personagens lhe dirige, em Fantasia para dois coronéis e uma piscina. A discussão da modalidade de focalização da voz narrativa e, correlacionadamente, do grau de presença e de omnisciência do narrador, constituem tópicos recorrentes desta indagaçáo autocrítica sobre os limites da ficção.

A reflexão metaficcional alarga-se à desconstrução do próprio estatuto do narrador, autoritário demiurgo no seu Olimpo (e se anuncia mesmo no texto como "autor totalitário"), mas ciente da sua fragilidade ontológica, com o narrador a afirmar de uma personagem - "Joel existe, eu não" -, lamenta-se nestes termos o narrador de Era bom que trocássemos umas ideias sobre o assunto, entre diversos exemplos.

Como seria de esperar, a desmontagem metaficcional da escrita de Mário de Carvalho estende-se às irónicas referências a certa cultura literária nem sempre bem assimilada e aos respetivos discursos teórico-críticos da moda - a propósito da impreparação de uma jovem jornalista, interroga-se o narrador: "Onde é que Eduarda tinha aprendido estas coisas todas? Blasé, interface, intertextualidade, frontispício, new age, paralaxe, pórtico, e mais um ror de palavras finais? Numa vasta Universidade que só funciona à noite e que tem plúrimos departamentos nos bares do Bairro alto e na Avenida 24 de Julho" (Carvalho 1995: 58).

Ainda nesta filosofia literária auto-reflexiva e proactivamente inovadora, ganha especial acuidade a viva teatralização da narrativa, em particular dos diálogos, muito ricos em reflexóes de teor metaliterário e metaficcional - procedimento que alterna com as reflexóes contidas no 
discurso das vozes narrativas -, e que tanto podem referenciar a Poética de Aristóteles e a Arte Poética de Horácio, como investir a organização do discurso narrativo de vários procedimentos cénicos, numa assinalável contaminação genológica.

Entre tantos outros processos narrativos objeto de auto-questionaçáo metaficcional - e esta ilustraçáo está bem longe de ser exaustiva -, o leitor pode reparar na justificação sobre a sobriedade dos traços psicológicos das personagens, a pretexto da reação de uma personagem (a jovem jornalista Eduarda Galvão), comentando o narrador: "A literatura é uma coisa muito séria, onde não entre o zapping. Eduarda tem um destino a cumprir e eu arranjarei maneira de a integrar na história em que tenha de fazer sair um deus duma máquina. Por agora, traço-a a pinceladas rápidas, de zarcão, despachadamente, não me atardo nos pormenores, prescindo das espessuras". E logo adiante, de forma mais explícita: "Eu náo queria entrar em pormenores psicológicos, porque tenho pressa, e prometi não aprofundar em excesso esta figura" (Carvalho 1995: 59, 61). A voz narrativa desnuda assim, diante do leitor, com ironia q.b., o seu programa de escrita.

Estes e outros procedimentos de índole ostensivamente metaficcional - típicos de uma narrativa narcisistica (cf. Hutcheon 1984: 23 ss.), nas modalidades de forma manifesta ("overt") ou dissimulada ("covert"), a nível ora linguístico, ora diegético - repetem-se e ampliam-se nas obras narrativas do referido corpus de Mário de Carvalho. Com destaque para algumas das mais recentes - Fantasia para dois coronéis e uma piscina e A Arte de Morrer Longe -, o gosto de contar histórias mostra-se indissociável de uma certa desestabilização vigiada e irónica da narrativa, insistindo-se na autorreflexão e desconstrução da estrutura da narração.

Ainda neste espírito autorreflexivo da escrita ficcional de Mário de Carvalho, de forte tessitura intertextual, frequentemente contaminado por um registo irónico e paródico, merece realce a divagação de matriz horaciana (Arte Poética), em torno dos "desvios" e "imaginaçóes" que perturbam a economia, a verosimilhança e a unidade da narrativa (Carvalho 2003: 15-16). Aliás, não deixa de ser irónico e até algo paradoxal que num "género sem lei” como o romance, Mário de Carvalho convoque amiudadas vezes a auctoritas da poética de Aristóteles ou de Horácio.

Também sobressai a variedade do intertexto das mais recentes narrativas, ao contrapor irónica e carnavalescamente - como ocorre frequentemente na escrita metaficcional - os autores canónicos a outros fenómenos sociológicos, desde os autores de best sellers da cultura de massas (de 
Ponson du Terrail a Paulo Coelho), incluindo a BD, a música pimba ou mesmo o lixo televisivo. Sem esquecer, neste piscar-de-olho irónico e até cáustico, as referências intertextuais e metaliterários a outros autores e obras, das ambíguas remissões a autores canónicos, como Eça de Queirós, Camilo Castelo Branco ou mesmo José Saramago, e sobretudo as farpas dirigidas a certos fenómenos de massas ou subprodutos de consumo kitsch, como a menção a "um livro adocicado do senhor Paulo Coelho" (Carvalho 2003: 33).

Como sugerido, nesta escrita metaficcional destaca-se o recurso à paródia como forma de ridicularização de certa gravitas literária, impeditiva sobretudo de todos os modos de institucionalizaçáo de formas e da natural exaustâo processos. A par dessa tão frequente associação da paródia à metaficcionalidade (cf. Macedo 2008: 73-81) na escrita de Mário de Carvalho, manifesta-se também a reiterada intenção de desorientar ambígua e provocatoriamente o leitor, ora desfazendo as fronteiras entre a referencialidade e a ficção; ora insistindo na ilusão dos mundos possiveis esteticamente criados, na sua variada tipologia (cf. Albaladejo 1986: 75-79; 1992: 49-52), sempre revelando formas de autoconsciência verbal e ficcional.

Pelo afirmado, conscientes da sua dimensão de artefacto literário, através de variadíssimos processos de auto-reflexividade constante, mesmo que em regime lúdico e paródico, estas narrativas de Mário de Carvalho instauram uma metaficcionalidade explícita e crescente, assumidamente configuradora de uma renovada ideia de romance ou de narrativa adequada aos tempos atuais. Por isso, não deveria constituir um desafio muito exigente às capacidades hermenêuticas do "experiente" e "sagaz" leitor; mas antes ser motivo de fruição estética e continuado gozo irónico e intelectual; e ainda constituir apelo constante à sua cooperação interpretativa e atitude crítico-reflexiva. Os vários narradores de Mário de Carvalho convidam, de certo modo, o leitor a pensar - com essas vozes narrativas - o destino ou o rumo do romance atual; continue esse género narrativo a chamar-se assim (romance) ou de outra maneira (uma nova designação para um género renovado), de modo a não confundir-se com um paradigma romanesco já inquestionavelmente ultrapassado.

Nesta atitude metaficcional e humorada, também ela bem típica de um espírito pós-moderno (e até pós-colonial), a escrita ficcional de Mário de Carvalho exorciza ainda, pelo humor e pela paródia constantes, certas fantasias e fantasmas do imaginário português. Por isso, não faltam referências ou alusóes, disseminadas pelas três narrativas referidas, a obras tão diversas como: i) a epopeia de Luís Camóes, com os seus contornos ideológicos e 
os ecos interpretativos até aos dias de hoje; ii) a História Trágico-Maritima e alguns dos seus mais conhecidos relatos de naufrágios, sem esquecer a sua forte simbólica anti-épica; iii) e José Saramago, assinalável fenómeno de popularidade e de receção, autor não isento de preconceitos e de controvérsias.

Deste modo, o imaginário cultural coletivo é constituído objeto da mesma alargada consciência crítica, frequentemente através do valor patrimonial e identitário de algumas das suas obras literárias. Por exemplo, num discurso irónica e corrosivamente contrário a certa retórica oficial do "nacional portuguesismo" - utilizadora abusiva de Os Lusíadas numa leitura redutoramente patriótico-nacionalista -, um reconhecível espírito anti-épico atravessa, por ex., Fantasia para Dois Coronéis e uma Piscina. É sobretudo visível desde a invocação inicial à Musa, passando pelas referências à História Trágico-Marítima e ao popular naufrágio de Sepúlveda (Carvalho 2003: 95, 141, 146); encerrando com uma irónica e subversiva paráfrase camoniana, exprimindo assim o cáustico olhar sobre a decadência do país: "Nô mais, ficção, nô mais! (...) Há emenda para este país?" (Carvalho 2003: 227).

Como se constata, nesta continuada e cativante tendência para metaficção paródica, Mário de Carvalho também desconstrói - numa dimensão também assumidamente interdiscursiva, e não meramente intertextual ou arquitextual - a seriedade anacrónica de mitos, valores, figuras ou narrativas identitárias, tradicionalmente configuradores de certa tradição, memória ou identidade coletiva. Isso é particularmente visível em determinada retórica oficiosa de engrandecimento do passado histórico e imperial da grande nação portuguesa - desde as épocas remotas da nossa História, passando pela época dos Descobrimentos e das tragédias dos naufrágios, até à "patriazinha iletrada" e incivilizada dos nossos dias, metaforizada na remota vila de Grudemil, num retrato desencantado do Portugal contemporâneo (cf. Martins 2011).

Esta vocação latamente metaficcional das narrativas de Mário de Carvalho assenta, como adiantando já, numa fecunda relação com a paródia e com procedimentos que lhe estâo habitualmente associados, da ironia à intertextualidade. A paródia metaficcional mostra-se assim um processo autocrítico de natureza especular: revelar os velhos processos como forma de distanciamento e de superação. Assim se compreendem processos como a densidade de uma repetida intertextualidade irónica; ou a frequente intromissão do narrador (ativo homo ludens) e a ênfase colocada em intervençóes sobre a ficcionalidade do ato de narrar, num con- 
tinuado e consciente processo de desocultação (cf. Waugh 2003: 63 e ss.). O objetivo é o de desestabilizar certas conceçóes através do estratagema de jogo ficcional:

Fictional play also reevaluates the tradicional procedures of communication and allows release from established patterns. Metafiction explicitly examines the relation of these procedures within the novel to procedures outside it, ensuring the survival through adaptability of the novel itself (Waugh 2003: 36).

Como seria de esperar, o leitor (e a sua enciclopédia) é habitualmente implicado neste jogo narrativo, sendo-lhe atribuído um papel bastante ativo e cúmplice, como participante indispensável no processo autocrítico da reflexão metaficcional (lector in fabula). O leitor é desafiado a seguir os desafios da voz narrativa e a ter uma palavra através de consciência crítica sobre os procedimentos literários que permitem a construçáo ficcional. Por conseguinte, a autorreflexividade narrativa mostra-se indissociável de um leitor cooperante, que adquira consciência dos procedimentos que conduzem ao artefacto narrativo:

Any text that draws the reader's attention to its processo of construction by frustrating his ou her conventional expectations of meaning and closure problematizes more or less explicity tha ways in which narrative codes (...) artificially construct apparently 'real' and imaginary worlds in the terms of particular ideologies while presenting these as transparently 'natural' and 'eternal' (Waugh 2003: 22)

Enfim, o leitor do discurso metaficcional perdeu a velha ilusão em paradigmas narrativos de outros tempos. A poética romanesca tradicional insistia, de diversos modos, na "verdade da ficção"; opostamente, a escrita metaficcional contemporânea desvenda a "ilusão da ficção", acentuando a ideia de artifício literário. Simplificadamente, são dois modos de entender o processo literário da representaçáo em que assenta a criação ficcional.

Numa palavra, a metaficção surge-nos como uma forma maior ou uma das faces mais visíveis do pós-modernismo literário atual; e no caso das narrativas referidas de Mário de Carvalho, são exemplos de ficçóes conscientes do seu próprio próprio processo, de forma manifesta, quer no 
plano linguístico, quer no diegético. Essa auto-reflexividade vai ao ponto de propor uma nova forma ou género narrativo.

\section{Cronovelema, futuro da ficção?}

Com efeito, a culminar este continuado pensamento metaficcional que estrutura especialmente a escrita do referido corpus de Mário de Carvalho, o leitor é confrontado com uma proposta algo ousada, mas repetida e consistente - ora implícita e difusa, ora assumida e expressa - de um novo modelo ficcional de romance (ou narrativa sua sucedânea). Aponta-se e particulariza-se, de forma ilustrada e argumentada, um modelo de narrativa liberto de peias e constriçóes impositivas, mais adequado ao mundo e ao ritmo contemporâneos, pondo diretamente em causa um determinado arquitexto do género romanesco e respetivos códigos tradicionais.

Constatamos, na sequência do afirmado antes e numa lógica recriadora, como a metatextualidade e a metaficção exploram os limites dos códigos estéticos e mesmo dos saberes estabelecidos, testando a incerteza e a porosidade das fronteiras entre géneros e discursos; e transformando assim a metaficção num projeto com uma componente política, como salientado por Jacques Sohier (in Lepaludier, 2002: 41).

Ou seja, nas referidas criações Mário de Carvalho assiste-se à configuração de um tipo singular de narrativa, chegando-se mesmo a concretizar, expressa e metaficcionalmente, a definição de uma nova forma de narrar. Numa palavra, no cerne da auto-reflexão deste autor, somos confrontados com a recodificação de um género narrativo. Deste modo, a desconstrução metaficcional a que assistimos tem o fecundo propósito de inaugurar uma nova forma literária, à luz de uma paródia dialética alicerçada na relação esgotamento/renovação.

Não embarcando em demagógicas e estéreis proclamaçôes da "morte do romance" (ou morte da própria literatura), este escritor mostra consciência das sucessivas metamorfoses do romance como género em permanente evolução e constante processo de autoavaliação crítica. Ao mesmo tempo, tem plena noção do que se pode aproveitar de uma rica história libertária, subversiva e metaficcional da escrita romanesca, de Cervantes a Sterne, entre outros autores das suas afinidades eletivas.

Definitivamente, nesta conceção vitalmente dinâmica e evolutiva do género, o romance ou a narrativa de hoje não podem imitar rigidamente um modelo passado (do paradigma balzaquiano à derivação realista ou 
naturalista, com diversas evoluçóes posteriores); nem sequer ficar-se pelos revolucionários modernizadores do romance a partir das primeiras décadas do séc. xx (Virgínia Woolf, James Joyce, Franz Kafka, etc.); nem ainda pelas sucessivas tendências novecentistas, da lost generation americana ao nouveau roman francês, do romance politicamente engagée à narrativa existencialista ou psicologista.

Enquanto "novo rico" ou "género sem lei" (lawless), o romance é por isso mesmo mais vocacionado e permeável para assumir sucessivas formas e discursos, exigidos pelo espírito do tempo em cada época, numa espécie de paráfrase livre do conhecido pensamento de Stendhal - com as devidas matizaçóes e reservas, não será o romance o espelho que se transporta ao longo do caminho da História? Auscultando as pulsóes do seu tempo, cada época molda um tipo diferenciado de romance, metamorfoseando anteriores conceçôes, num processo de renovação imparável (cf. Raimond 1989).

Afinal, parafraseando J. Ortega y Gasset, como pode alhear-se a ficção de hoje do homem atual e das suas circunstâncias? Porém, perante esta formulação, logo se ergue a argumentação conhecida: náo é essa uma conceção redutoramente sociológica e mimética? Não necessariamente, antes forma artística de representação com os naturais mecanismos efabuladores da imaginação criadora. Retomando a mesma perigosa imagem, o romance será o espelho transfigurador, assente na construção de universos ficcionais, podendo variar significativamente os índices, os cambiantes e os procedimentos usados na refração da matéria espelhada.

Qualquer semelhança entre esses mundos possíveis e a realidade circundante não é mera coincidência... Mesmo quando a representação literária (mimesis) é ironicamente questionada, com o narrador a desnudar-se perante o leitor, confessando que não conseguiu inventar melhor; ou quando, de modo igualmente jocoso, reflete sobre os seus intentos em matéria de verosimilhança. Mesmo nestes casos, manifesta-se o desejo de contar uma história dotada de determinado efeito de real, onde sobressai a centralidade da auto-consciente entidade enunciadora do discurso narrativo (cf. Waugh 2003: 2). No entanto, a funcionalidade reguladora e reflexiva da voz do narrador intrusivo, ironicamente assumida e provocatória, ao mesmo tempo que denuncia a exaustáo de velhos processos, também se distancia de alguns procedimentos demasiado experimentais:

"Daqui a bocado preciso de dirigir uma pequena interpelação ao Joel Strosse, e, até lá, não convém que fique nada por elucidar. Se não fosse abusar, até usava alíneas e limitava-me a substantivos. Mas como 
costumo ficar incomodado das habilidades modernaças, armadas ao pingarelho, com que a minha concisão poderia confundir-se, forço-me, por disciplina, a debitar texto, embora escasso. Onde é que eu ia?" (Carvalho 1995: 112).

Assim, não possuindo nem uma poética prescritiva, nem um cânone rígido, como outros géneros multisseculares, o romance mostra-se um género em devir, uma forma aberta, para recorrermos à conhecida conceituação de G. Lukács. Ora, também para Mário de Carvalho, nos tempos atuais se impóe justamente uma reflexáo em torno dos novos rumos e natureza genológica do romance. Para este autor, na sua postura obsessivamente metaficiconal, é urgente refletir sobre uma poética ou uma prática de escrita mais adequadas às novas circunstâncias. Ao mesmo tempo, implicitamente, o autor mostra consciência da relativa novidade da sua proposta, uma vez que ela se insere no âmbito de uma tradição ficcional que remonta, pelo menos, aos sécs. XVIII e XIX.

Observe-se, aliás, que essas liberdade e inventividade genológicas em Mário de Carvalho são já visíveis a partir da obra seminal $O$ Grande livro de Tebas navio e Mariana (1982); mas tornam-se particularmente notórias em obras mais recentes como as destacadas antes. Ou seja, esse percurso indagador de novos rumos é particularmente notório em Era Bom que trocássemos umas ideias sobre o assunto (1995). Curiosamente, nesta narrativa, a discussão crítico-ideológica em torno do estado da "esquerda pós-moderna", em finais do séc. xx e no contexto português, parece-nos de algum modo análoga à própria indagação crítico-paródica sobre o novo rumo da ficçáo contemporânea. A denúncia dos processos anacrónicos de adesão e de funcionamento do PCP também pode ser lida, até certo ponto, como símile da necessidade de superaçáo das velhas formas e processos romanescos. Recorrendo à linguagem de influentes ensaístas como George Steiner, somos testemunhas da falência de grandes narrativas, num denominador comum de crise instalada.

Afinal de contas, a dois níveis distintos (político e estético-literário), a sociedade e a cultura pós-modernas impóem uma rutura com os modelos do passado, exigindo uma tentativa de superação. As grandes metanarrativas ocidentais, sejam elas ideológicas, religiosas ou culturais, entraram também elas em crise manifesta e irremediável. Como realçado pelo pensamento pós-moderno, essas narrativas fundadoras já não se mostram detentoras da verdade, nem são capazes de explicar o mundo; por isso, se voltam para si próprias num processo de autoquestionamento. Como salientado no conhecido pensamento mais radical de Jean Baudrillard, os poderes e 
os discursos falam atualmente de si próprios, através da simulação, para contornar a sua agonia real.

Em Mário de Carvalho, esse desejo de refundação da escrita ficcional ora reabilita certa lição ou presença dos clássicos intertextualmente convocados (de Fernão Lopes a Eça de Queirós, sem esquecer certa tradição anglo-americana); ora vitupera todas as formas de epigonismo estético, bem como os usos chocantemente empobrecedores e bárbaros da língua portuguesa, enquanto sistema modelizante primário e fundacional do próprio sistema literário. Essa aguda e consciência da herança intertextual (tradiçâo literária) é assumida sem ansiedades edipianas ou "angústia da influência" (Carvalho 2010: 110), antes expressa de forma irónica, lúdica e sadia: "A quem escreve, faz sombra esta barreira constante, eriçada de farpas, daquilo que outros mais expeditos ou temporãos escreveram antes" (Carvalho 1995: 50). Noutro passo da mesma obra, a voz narrativa reincide em manifestaçóes de autorreflexividade sobre o mesmo tópico dos débitos literários, de reconhecimento sempre tão difícil por parte dos escritores: "Estes pensamentos não são meus que náo quero ferir suscetibilidades de criadores de dobermans, mas eram mais ou menos descontando a parte do Ray Bradbury - os de Joel Strosse" (Carvalho 1995: 259).

Já a censura contra os desmandos e os atropelos da língua constitui uma sátira reiterada e violenta, apresentando-se a voz narrativa como atento vigilante dos condenáveis atropelos linguísticos - “(...) nós, viajantes do vocabulário, da semântica”. São sobretudo narradores bem conscientes do trabalho sobre a língua exigido pela criação literária, quase evocando implicitamente a velha lição dos clássicos (labor et lima): “Um dia, leitor, hei de contar as ânsias e tormentos com que se vai martelando esta artesania da escrita" (Carvalho 2003: 19, 216). Depreende-se daqui uma conceção modelar e vigilantemente crítica do romance - ou dos seus sucedâneos em matéria de língua.

Porém, é sobretudo em dois romances mais recentes que Mário de Carvalho expressamente, e através das vozes intrusivas e controladoras, de preocupaçóes metaficcionais, enuncia melhor a sua conceção de um novo rosto para a escrita ficcional, quando propóe o neologismo e define o conceito de cronovelema - género compósito e híbrido, que agrega as convençóes de outros géneros, desde a agilidade narrativa e reflexiva da crónica, até ao caráter efabulador da novela, sem esquecer ainda nessa súmula renovadora a contençáo do conto, a hibridez do poema em prosa e ainda, last but not least, o dinamismo narrativo próprio do cinema. 
A natureza deste género híbrido torna-se visível, por exemplo, na singular abordagem do tempo, na dinâmica estruturação do discurso narrativo (ordo naturalis / ordo artificialis), nas mudanças de ponto de vista, na alternância de planos (do plano geral para o pormenor do close-up e vice-versa, v.g.), nas inesperadas alteraçóes de níveis narrativos (metalepses frequentes), na sobriedade da análise psicológica, entre outras opções.

Em Fantasia para Dois Coronéis e uma Piscina, depois de problematizar em registo metaficional vários aspetos da estrutura narrativa; e até de citar, parafraseadamente, a Poética de Aristóteles como texto fundacional da teorizaçáo da narrativa - para definir o que entende por "entrecho" e "açáo", bem como a "elevação da linguagem" face à "verdade dos factos" (Carvalho 2003: 16 e 54) -, a voz narrativa justifica-se perante o leitor, a fim de lhe explicitar uma nova forma de narrativa, com sua poética e ritmos próprios: "Este [texto] em que flanamos - chamemos-lhe cronovelema - propóe-se narrar. E isso demanda o seu tempo e os seus tempos" (Carvalho 2003: 34 , itálico nosso). Sob o pretexto de um balanço ou acerto de contas com o passado (com o empenhamento político-partidário e com a Revolução dos Cravos), a narrativa configura-se, de facto, como retrato satírico de um certo Portugal contemporâneo e vulgar, porque inculto e alienado.

Em entrevista, o escritor definirá cronovelema como uma narrativa híbrida, composta por diferentes géneros - a novela, a crónica, o cinema e mesmo a poesia (cf. Martins, 2003: 12). Nesta proposta renovadora, fica patente o jogo a que o narrador submete, de modo ostensivo, a linguagem, os géneros e as convençóes estético-literárias.

Finalmente, em A Arte de Morrer Longe (2010), o retrato satírico da vida conjugal de Arnaldo e Bárbara, e da ameaça de divórcio de um jovem casal desavindo - alegoria demolidora de certo vazio de valores que corrói a sociedade atual, minando as relaçóes interpessoais - corre a par da proposta explícita de um novo modelo de escrita ficcional, o novo género literário designado de cronovelema, "invençâo de certo escritor que amanhã nomearei” (Carvalho 2010: 99), afirma o narrador, que assim convoca o autor para o universo ficcional. Já anteriormente o mesmo narrador se tinha referido à "verdade contida numa das últimas linhas de diálogo deste cronovelema” (Carvalho 2010: 71). Aliás, não deixa de ser significativo que A Arte de Morrer Longe seja a primeira narrativa de Mário de Carvalho a assumir, de modo explícito e peritextual (com a liberdade que assiste ao autor), a designação genológica de cronovelema, inscrita na própria capa da obra. 
Três corolários breves, a terminar: em primeiro lugar, estas e outras narrativas parecem corresponder a uma acentuada evolução (ou inflexão) da escrita ficcional de Mário de Carvalho, observável a partir da década de 1990 - no sentido de um certo abandono (temporário?) da revisitação histórica ou de universos mais fantasiosos, em favor de um realismo quotidiano, atraído por uma contemporaneidade decadente, desencadeadora da postura crítica adotada pelo escritor, num estilo manifestamente tocado pelas cores irónicas do pícaro, do satírico desencanto ou da paródia carnavalizadora, à sombra de uma ética da vigilância crítica (cf. Martins, s.d.).

Lendo estes e outros textos ficcionais de Mário de Carvalho, encontra-se facilmente um denominador temático comum. Assim, não parece ser possível ficar indiferente às manifestaçóes da pseudo-cultura e ao oportunismo descarado de autores, editores e produtores culturais; mas também às manifestaçóes de baixa cultura, ao jornalismo incompetente, aos profissionais oportunistas e impreparados, à anacrónica forma de militância política, à corrupçấo interiorizada e impune; e ainda ao desinteresse pela causa pública, aos vícios congeniais da mentalidade coletiva, enfim, à "descidadania da lusitana gente" (Carvalho 2003: 84) - sociedade de aparências e simulacros (Jean Baudrillard), que promove a ignorância e a alarvidade, desde a literatura à vida profissional e social. Ora, a proposta conceção de renovado romance ou de cronovelema não é indiferente a este contexto cultural, podendo agir crítica e agudamente sobre ele. Perante esta nova realidade e cosmovisão do séc. XXI, não é possível continuar a contar uma história com um paradigma romanesco de tempos pretéritos, divorciado da realidade atual.

Em segundo lugar, pode equacionar-se outra questão: a reiterada representação, tantas vezes em registo caricatural, de um presente alienado e bárbaro, tal como descrita nestas e em outras narrativas do autor, representa a nostalgia de tempos pretéritos? À imagem de certa ideologia da geração de 70 e de Eça de Queirós, a decadência do Portugal contemporâneo contrasta com a dimensão heroica do Portugal de outrora, sobretudo com a nação aventureira celebrada por Camóes? A escrita de Mário de Carvalho recusa retóricas ultrapassadas, visóes idealizadas de um certo Portugal ou insustentáveis conceçóes patrioteiras; antes, sem saudosismos serôdios, se detém num retrato desventurado do "teatro do quotidiano", dizendo o desencanto português de hoje. 
Por outras palavras, cremos que a escrita de Mário de Carvalho, inovadora, prazenteira e cáustica, náo se identifica com o referido tipo de nostalgia ou contraponto ideológico fácil (oposição passado/presente, e portanto longe da esgotada tópica do laudator temporis acti). Antes constrói a representação de um certo Portugal presente à luz de um ideário de fundo humanista e ético, através de desencantadas "meditaçóes morais" (Silvestre 1998) sobre o destino coletivo: "Há emenda para este país?" - interroga-se no explicit de um dos romances (Carvalho 2003: 227).

Assim, a escalpelizada realidade circundante, várias décadas após a revolução de 1974, está bem longe de corresponder aos ideais emancipatórios e aos padróes de equilibrado desenvolvimento que se esperavam de uma sociedade democrática e evoluída. É neste quadro disfórico que se entende, nos territórios ficcionais de Mário de Carvalho, a recorrente e acutilante descrição de certos espaços e de comportamentos de heróis sem qualidades.

A título de eloquente exemplo, atente-se naquele "herói sem nenhuma conquista", tal como é apresentado Joel Strosse, por ex., em Era bom que trocássemos umas ideias sobre o assunto, homem de 50 anos, testemunha da Revolução de 1974, mas preso à rotina burocrática do trabalho numa Fundação. Ou recordem-se ainda os ociosos coronéis de Fantasia para dois coronéis e uma piscina, sem consciência da sua ridícula inutilidade.

Em todo o caso, como sugerido, esta conceçáo renovada de romance, ou de cronovelema, como forma de narrativa ancorada na contemporaneidade, não enjeita a longa herança do género romanesco; antes pretende adequar-se mais fielmente à filosofia ou mundividência destes tempos pós-modernos, aos seus novos valores, outros ritmos de vida e renovados códigos estéticos.

Finalmente, e como corolário do exposto, presenciamos a configuração gradativa e metaficcional de um novo género ou conceçáo libertária e atualizada de narrativa, na reflexiva pena de Mário de Carvalho. Por um lado, a escrita do autor recupera e celebra uma certa tradição ficcional (de Cervantes aos clássicos anglo-americanos como Lawrence Sterne ou Charles Dickens), apostada ela própria em reinventar, metanarrativamente, a arte da ficção, através de um novo realismo e até do grotesco quotidiano, mas também através de uma cultura do humor e da paródia, concebidos na sua funçấo eminentemente crítica. Desde pelo menos a teoria literária dos formalistas russos que, como referido, à paródia é reconhecido um papel decisivo no processo de evoluçáo literária, como processo privilegiado de desautomização de convençôes literárias. 
Por vezes, e isso é visível no emprego de um vasto leque de recursos formais do humor e da paródia, a escrita ficcional de Mário de Carvalho tem ainda um alvo privilegiado - a denúncia de certa tópica ficcional e retórica vazia -, aproximando-se assim do humor de um Flaubert, em Dictionaire des Idees Reçues, mas operando uma ampla caricatura que se estende da matéria literária aos clichés sentimentais. Ou seja, distinguindo-se como escrita de consciência paródica, opera uma espécie de purgação ou denegação do estereótipo e do epigonal; numa palavra, tem horror ao já gasto e ao já dito.

Por outro lado, a escrita metaficcional de Mário de Carvalho insiste na ideia de que esta conceção híbrida e libertária de poética ficcional é a mais adequada aos novos tempos em que vivemos, onde a tessitura narrativa congrega a criação efabuladora com a dimensão reflexiva de um narrador-cronista, obcecado em traçar uma anatomia provocatória e impiedosa do mundo de hoje, num impulso hilariantemente corrosivo: narrativa ágil com o ritmo da novela (picaresca ou de aventuras) ou mesmo do cinema; sobreposta ou enriquecida pela dinâmica estilística e reflexiva da crónica. Os gérmenes deste género híbrido já constavam da rica história do romance; mas Mário de Carvalho teve a lucidez de os acentuar.

Como analisado por Jean Bessière (2010: 31 e ss.), tendo-se tornado no género hegemónico no sistema literário moderno e contemporâneo, universalmente cultivado e reconhecido, não surpreende que o romance também se tenha transformado em espaço privilegiado de modalidades reflexivas plurais, superadoras de velhos paradigmas do género, bem como de limites e convençôes da própria escrita literária. No caso português, como se procurou demonstrar, a obra ficcional de Mário de Carvalho mostra-se um caso raro como ato de pensar, metaficcional e ironicamente, a escrita narrativa e romanesca - desconstruindo velhas ontologias e problematizando categorias tradicionais, para assim ousar propor novos rumos à narrativa contemporânea. 


\section{Bibliografia Geral}


(Página deixada propositadamente em branco) 


\section{Ediçôes de Mário de Carvalho}

(21990), Contos da sétima esfera. Lisboa, Caminho.

(1991), Quatrocentos mil sestércios. Lisboa, Caminho.

(71991), Casos do beco das sardinheiras, Lisboa, Caminho.

(31993), A Paixão do Conde de Fróis. Lisboa, Caminho.

(1996), Os Alferes. Lisboa, Caminho.

( $\left.{ }^{3} 1996\right)$, O livro grande de Tebas, Navio e Mariana. Lisboa, Caminho.

(1997), Um deus passeando pela brisa da tarde, Lisboa, Caminho.

$\left({ }^{3} 1997\right)$, Fabulário. Lisboa, Caminho.

(52003), Era bom se trocássemos umas ideias sobre o assunto. Lisboa, Caminho.

(32004), Fantasia para dois Coronéis e uma Piscina. Lisboa, Caminho.

('2006), A inaudita guerra da Avenida Gago Coutinho. Lisboa, Caminho.

(2008), A sala magenta. Lisboa. Caminho.

(2010), A Arte de Morrer Longe. Lisboa, Caminho.

\section{Estudos}

Adorno, T. W. ('1983), "Posição do narrador no romance contemporâneo". In: Benjamin, Honkheimer, Adorno, Habermas. Trad. port. José L. Grünnewald et alii. São Paulo, Abril Cultural: 269-273.

Albaladejo, T. (1986), Teoría de los mundos posibiles y macroestructura narrativa. Alicante, Universidade de Alicante.

Albaladejo, T. (1992), Semántica de la narración: la ficción realista. Madrid, Taurus.

Albérès, R. M. (1972), Métamorphoses du roman. Paris, Albin Michel.

Almeida, J. F. (1997), Bíblia Sagrada. Rio de Janeiro, Fecomex (Ed. Revisada e corrigida).

Alves, C. C. (2010) "Vestígios do trágico em Mário de Carvalho”. Navegaçôes 3. 1: 53-58.

Anacleto, M. T. (1996), “(Sub)versions du "cliché” romanesque au XVII siècle: le "roman bourgeois" de Furetière”, Confluências 14: 97-109.

Angelini, P. R. K. (2011) "Recensão de Carvalho, M. A arte de morrer longe. Lisboa, Caminho, 2010. 128p.”. Navegaçōes 4. 1: 131-133.

Arnaut, A. P. (2001), "Donas e donzelas n'a Demanda do Santo Graal”, Santa Barbara Portuguese Studies. Califórnia, n. 5: 29-71. 
Aristófanes (21989), A Paz. Tradução de Silva. M. F. Coimbra, Instituto Nacional de Investigação Científica.

Aristófanes (2006), As Aves. Tradução de Silva, M. F. Lisboa, Edições 70.

Aristóteles (1986), Poética. Tradução de E. Sousa. Lisboa, Fundação Gulbenkian.

Arnaut, A. P. (2002), Post-Modernismo no romance português contemporâneo. Fios de Ariadnemáscaras de Proteu. Coimbra, Almedina.

Assis, A. K. T. (2008), Arquimedes, o centro de gravidade e a lei da alavanca. Montreal, Apeiron Montral.

Auerbach, E (1976), Mimesis (A representação da realidade na literatura ocidental). São Paulo, Perspetiva [1 $1^{\text {a }}$ ed., 1946].

Aurélio, Marco (1971), Pensamentos. Versão de João Maia. Lisboa, Editorial Verbo.

Bakhtine, M. (1970), La Poétique de Dostoievsky. Paris, Éd. du Seuil.

Bakhtine, M. (1981), Dialogic imagination: four essays. Austin, University of Texas Press.

Bakthine, M. (1981), Problemas da poética de Dostoievski. Trad. port. Paulo Bezerra. Rio de Janeiro, Ed. Forense-Universitária.

Benjamin, W. (1985), "Sobre o conceito de História. Tradução de Sérgio Paulo Rouanet”. In: Obras escolhidas. Magia e técnica, arte e política. São Paulo, Editora Brasiliense: 222-232.

Bessière, J. (2010), Le roman contemporain ou la problemacité du monde. Paris, PUF.

Beye, C. R. (1964), "Homeric battle narrative and catalogues", Harvard Studies in Classical Philology 68: 345-373.

Bergson, H. (2001), O riso: ensaio sobre a significação da comicidade. Trad. port. Ivone C. Benedetti. São Paulo, Martins Fontes.

Bhabha, H. K. (1998), O local da cultura. Belo Horizonte, Editora UFMG.

Bianchet, S. B. (2004), Petrônio. Satyricon. Edição bilíngüe. Belo Horizonte, Crisálida.

Bougnoux, D. (1991), "Le principe d'identification”. In Personnage et Histoire Littéraire. Toulouse, Presses Universitaires du Mirail: 187-195.

Brandão, J. L. (2001), A poética do Hipocentauro: Literatura, sociedade e discurso ficcional em Luciano de Samósata. Belo Horizonte, Ed. UFMG.

Brasete, M. F. (2003), “A crítica às mulheres no fr. 7 de Semónides de Amorgos”. In: Mora, C. M. (ed.), Sátira, Paródia e Caricatura: da Antiguidade aos nossos dias. Aveiro, Universidade de Aveiro: 39-56.

Brauner, E. F. (2009), “" Era bom que trocássemos umas ideias sobre o assunto”: ironia de um narrador e discussão do romance", Revista Electrónica de critica e teoria de literaturas. Dossiê: o romance português e o mundo contemporâneo 5. 2. Porto Alegre: 1-9.

Buescu, H. (1995), A Lua, a Literatura e o Mundo. Lisboa, Cosmos. 
Buescu, M. L. C. (1979), Aspectos da herança clássica na cultura portuguesa. Lisboa, Instituto de Cultura Portuguesa.

Camôes, L. (1979), Os Lusíadas. Prefácio de Hernâni Cidade. São Paulo, Abril Cultural.

Carcopino, J. (1993), La vida cotidiana en Roma en el apogeo del imperio, trad. esp. Madrid, Ediciones Temas de Hoy.

Cardoso Bernardes, J. A. (1988), O Bucolismo Português. A égloga do Renascimento e do maneirismo. Coimbra, Livraria Almedina.

Carvalho, M., (2003), "Mário de Carvalho: crónica do aturdimento". JL - Jornal de Letras, Artes e Ideias 864, 12/11: 12.

Ceia, C. (2007), A Construção do romance (Ensaios de literatura comparada no campo dos estudos anglo-portugueses). Coimbra, Almedina.

Chevalier, J., Gheerbrant, A. (1994), Dicionário dos Símbolos, trad. port., Lisboa, Editorial Teorema.

Colaço, J. (1995), “Mário de Carvalho”, Biblos. Enciclopédia verbo, I, s.u.

Compagnon, A. (2001), O demônio da teoria: Literatura e senso comum. Belo Horizonte, Editora UFMG.

Constâncio, N. (2007), Ruinas e incertezas em "Um Deus passeando pela brisa da tarde”, de Mário de Carvalho. Lisboa, Edições Colibri.

Costa, L. S. (1995), “Era Bom que Trocássemos Umas Ideias Sobre O Assunto, de Mário de Carvalho. A Arquitectura, A Violência”. In: Público/Leituras, 11 de Novembro:10.

Cotrim, J. P. (1996), Entrevista a Mário de Carvalho: "Alguma coisa me perturba”. Ler/Livros e Leitores 34: 45.

Cotrim, J.P. (1996), "Mário de Carvalho. O Mistério da Literatura”, entrevista ao autor. LER 34, Primavera.

Cristóbal, V. (1992), "Búsqueda de campo, hastío de ciudad. Pasión antigua y contemporánea”. In: Guzmán, A. et alii (ed.), Aspectos modernos de la Antigüedad y su aprovechamiento didáctico. Madrid, Ediciones Clásicas: 131-143.

Davison, M. (1976), "The thematic use of ekphrasis in the ancient novel”, in Erotica antiqua. Acta of the International Conference on the Ancient Novel. Bangor, ICAN: 32-33.

Devereux, G. (1975), Dreams in Greek tragedy. Oxford, Basil Blackwell.

Dijksterhuis, E. J. (1987), Archimedes. Translated by C. Dikshoorn. Princeton University Press.

Diogo, A. A. L. (1997), "Exórdio". In: Biblos- Enciclopédia Verbo das Literaturas de Lingua Portuguesa. Lisboa, São Paulo, Verbo.

D’Onofrio, S. (1978), Poema e Narrativa: estruturas. São Paulo, Duas Cidades. 
Duncan, T.S. (1935), “The deus ex machina in Greek Tragedy”. Philological Quarterly 14: $126-141$.

Dunn, F. M. (1985), Euripidian Endings: a Study of the Choral Exit, the Action, the Concluding Prophecy and the Deus ex Machina. Yale University: 111-167.

Eco, U. (1979), Leitura do Texto Literário. Lector in Fabula. Trad. Mário Brito. Lisboa, Presença.

Entrevista com Mário de Carvalho http://www.homemmag.pt/pt/index.php/arte-e-literatura/arquivo-arte-literatura/87-luisa-costa-gomes-entrevista-mario-de-carvalho

Ernout, A. ( $\left.{ }^{11} 1993\right)$, Pétrone. Le Satyricon. Paris, Les Belles Lettres.

Ernout A, Meillet, A. ( $\left.{ }^{4} 1967\right)$, Dictionnaire etymologique de la langue latine: histoire des mots. Paris, Librairie C. Klincksieck.

Errandonea, I. (1954), Diccionario del mundo clásico. Barcelona, Editorial Labor.

Eschilo ( $\left.{ }^{4} 2000\right)$ I sette contro Tebe. Con testo a fronte. Introd. Umberto Albini. Trad. Ezio Savino. Milano, Garzanti Editore.

Feijóo, B. (1998), Um Não Sei Quê. Lisboa, Vega [1746].

Ferreira, C. (2003), “Mário de Carvalho. A arte de bem iludir o leitor”. In: Rodapé: 45-51.

Ferreira, P. S. (1999), “A paródia e as suas implicações didácticas”. In: Torrão, J. M. N. (ed.), III Colóquio Clássico - Actas. Aveiro, Universidade de Aveiro: 113-137.

Ferreira, P. S. (2000), Os elementos paródicos no Satyricon de Petrónio e o seu significado. Lisboa, Colibri.

Ferreira, P. S. (2003), “Paródia ou paródias?”. In: Mora, C. M. (ed.), Sátira, Paródia e caricatura: da Antiguidade aos nossos dias. Aveiro, Universidade de Aveiro: 279-300.

Fialho, M. C. (1992), Luz e trevas no teatro de Sófocles. Coimbra, Instituto Nacional de Investigação Científica.

Figueiredo, M. N. (2006), "Com humana crueldade se tece um conto. A propósito de Homenagem ao Papagaio Verde”. In: Santos, G. (ed.) Jorge de Sena: Ressonâncias e Cinqüenta Poemas. Rio de Janeiro, 7Letras.

Fowler, D. P. ((1991), "Narrate and describe: the problem of ecphrasis", Journal of Rhetorical Studies 81: 25-35.

Frow, J. (1986), “Spectacle Binding: On Character”. Poetics Today 7. 2: 227-250.

Gaffiot, F. (1934), Dictionnarie Illustré Latin-Français. Paris, Librairie Hachette.

Garrett, A. (1973), Viagens na minha Terra. Rio de Janeiro, Editora Três.

Genette, G. (1972), Figures III. Paris, Ed. du Seuil.

Gennete, G. (1997), L'Cuvre de l'Art. La Relation Esthétique, II. Paris, Ed. du Seuil.

Genette, G. (2004), Métalepse. Paris, Ed. du Seuil.

Gomes da Torre, M. (1992), “Acerca da tradução da metáfora”. Linguas e Literaturas 9: 209-226. 
Grimal, P. (s/d), Dicionário de Mitologia Grega e Romana. Lisboa.

Guillén, J. (1977), Vrbs Roma - vida e costumbres de los romanos, vol. I: La vida privada. Salamanca, Ediciones Sígueme.

Guthrie, W. K. C. (1976), Les Sophistes. Paris, Payot.

Halliwell, S. (1968), Aristotle's Poetics. Chicago and London.

Hamon, P. (1976), “O que é a descrição?”. In: Seixo, M. A. (ed.), Categorias da narrativa. Lisboa, Arcádia: 61-83.

Hardwick, L. (2003), Reception Studies. Greece and Rome. New Surveys in the Classics. Oxford, Oxford University Press. [recensão do livro por Martin M. Winkler, in Bryan Mawr Classical Review 2004].

Heródoto. (2002), Histórias. Livro I. Tradução de Ferreira, J. R., Silva, M. F. Lisboa, Ediçóes 70. Heródoto (1997), Histórias. Livro III. Tradução de Silva, M. F., Abranches, C. Lisboa, Ediçóes 70. Heródoto (2000), Abranches, C., Histórias. Livro IV. Tradução de Silva, M. F., Abranches, Lisboa, Edições 70.

Homero (2003), Odisseia. Tradução de Frederico Lourenço. Lisboa, Livros Cotovia.

Homero (2005), Ilíada. Tradução de Frederico Lourenço. Lisboa, Livros Cotovia.

Hoorn, J. F., and Konijn, E. A. (2003), "Perceiving and experiencing fictional characters: An integrative account”. Japanese Psychological Research 45. 4: 250-268.

Horácio (1975), Arte Poética. Tradução de R. M. R. Fernandes. Lisboa, Clássica Editora.

Hutcheon, L. (1977), “Modes et formes du narcisisme littéraire”. Poétique 29: 90-106.

Hutcheon, L. (1984), Narcissistic Narrative. The Metafictional Paradox. New York and London, Methuen.

Hutcheon, L. (1985), A Theory of Parody. The Teachings of Twentieth Century Art Forms. New York \& London, Methuen; (1989), Uma teoria da paródia, trad. port. Lisboa, Ediçóes 70.

Hutcheon, L. (1988), A poetics of Postmodernism. History, Theory, Fiction. New York/London, Routledge; (1991), Poética do Pós-Modernismo. Trad. Ricardo Cruz. Rio de Janeiro, Imago.

Hutcheon, L. (2000), Teoria e Política da Ironia. Trad. port. Julio Jeha. Belo Horizonte, Editora UFMG.

Immerwahr, H. R. (1966), Form and thought in Herodotus. University of North Carolina.

Izaac, H. J. ( ${ }^{3} 1969$, 1973), Martial. Épigrammes, I-II. Paris, Les Belles Lettres.

Jauss, H. R. (1986), Experiencia y Hermeneutica Literaria. Ensayos en el campo de la experiencia estétca. Madrid, Taurus, [1977].

Jenny, L. (1979), "A estratégia da forma”, Poétique. Revista de teoria e análise literárias. Trad. port. Clara C. Rocha. Coimbra, Almedina: 5- 49. 
Jerome, K. J. , “Three men on the Brummel'. In: http://www.gutenberg.org/catalog/world/ readfilefk_files $=2061881$

Jourdan, P. (1996), "Paul Valéry chasseur de perroquets", Confluências 14: 51-59.

Júdice, N. (1997), Viagem por um século de Literatura Portuguesa. Lisboa, Relógio d'Água.

Julien, Y. (1998), Aule-Gelle. Les nuits attiques, IV. Paris, Les Belles Lettres.

Jurado, F. G. (1999), "Apuntes para una historia prohibida de la literatura latina en el siglo XX: La voz de los lectores no académicos”. In: Morán, M. C. A.; Iglesias Montiel, R. M. (eds.), Contemporaneidad de los clásicos en el umbral deI tercer milenio. Actas deI Congreso Internacional Contemporaneidad de los clásicos: La tradición greco-latina ante el siglo XXI. La Habana, Universidad de Murcia: 77-85.

Kerferd, G. B. (2003), O movimento sofista. Trad. port. Margarida Oliva. São Paulo, Ediçôes Loyola.

Kirk, D. M. (1960), The digression, its use in prose fiction from the Greek romance through the eighteenth century. Stanford University.

Kristeva, J. (1974ª), Introdução à semanálise. São Paulo, Perspectiva.

Kuester, M. (1992), Framing Truths - Parodic Structures in Contemporary English-Canadian Historical Novels. Toronto/London, Toronto University Press.

Lausberg, H. (1963), Elementos de retórica literária. Trad. port. Raul M. Rosado Fernandes, Lisboa, Gulbenkian.

Leão, D. F. (1996), “Trimalquião: a humanitas de um novo-rico”. Humanitas 48: 161-182.

Leão, D. F. (1997), “Trimalquião à luz dos Caracteres de Teofrasto”. Humanitas 49: 147-167.

Leão, D. F. (1998), As Ironias da Fortuna. Sátira e Moralidade no Satyricon de Petrónio. Lisboa, Colibri.

Leão, D. F. (2004), “Zoilo e Trimalquião, duas variaçôes sobre o tema do novo-rico”. Humanitas 56: 191-208.

Leão, D. F. (2004a), “O Satyricon de Petrónio e a crise dos paradigmas tradicionais”. In: Nascimento, A. (ed.), Antiguidade Clássica: Que fazer com este património?. Lisboa, Centro de Estudos Clássicos: 233-242.

Leão, D. F. (2005), Petrónio. Satyricon. Lisboa, Cotovia.

Lepaludier, L (2002), Métatextualité et métafiction. Théorie et analyses, Presses Universitaires de Rennes, CRILA.

Levi, P. (1988), É isto um homem? Rio de Janeiro, Rocco.

Lévy, E. (1983), "Le théâtre et le rêve: le rêve dans le théâtre d'Eschyle", in Zehnacker, H. (ed.), Théatre et spectacles dans l'Antiquité. Actes du Colloque de Strasbourg. Leiden: 141-168.

Lopes, S. R. (2003), Literatura, Defesa do atrito. Lisboa, Copiart. 
Lourenço, E. ('1982), "Da literatura como interpretação de Portugal”. In O Labirinto da Saudade (Psicanálise Mitica do Destino Português). Lisboa, D. Quixote: 85-126.

Lourenço, F. (2003), Homero. Odisseia. Lisboa, Cotovia.

Luciano (1996), Uma história verídica. Tradução de C. Magueijo. Lisboa, Editorial Inquérito Limitada.

Lukács, G. (1989), Théorie du roman. Paris, Flammarion [1916].

"Na Lusitânia com Mário de Carvalho (História, paródia e ironia em Quatrocentos mil sestércios e Um deus passeando pela brisa da tarde)". In Veredas 5 (2002) 211-224.

Macedo, A. G. (2008), Narrando o pós-moderno: reescritas, revisôes, adaptaçôes. Braga Universidade do Minho.

Machado, J. P. (1995), Dicionário etimológico da Língua Portuguesa. Lisboa, Livros Horizonte.

Malina D. (2002), Breaking the frame: metalepsis and the construction of the subject. Columbus, Ohio State UP.

Margolin, U. (2005), “Character”. In: Herman, D., Jahn M., Ryan, M.-L. (eds.), Routledge Enciclopedia of Narrative Theory. London/New York, Routledge: 54-57.

Marinho, M. F. (1996), "O sentido da história em Mário de Carvalho", Revista da Faculdade de Letras. Linguas e Literaturas: 257-267.

Marinho, M. F. (2010), "À la recheche de l'identité perdue. Essai sur la crise d'identité dans le roman portugais contemporain”. In: Besse, M. G. \& Ralle, M. (eds.), Les Grands Récits: Miroirs Brisés? Paris, Índigo:186-198.

Martin, F. (1987), Les mots latins. Paris, Hachette.

Martins, J. C. O. (2011), "Mário de Carvalho e a reflexão metaficcional sobre o futuro do romance”. Diacrítica. Dossiê Literatura e Religiāo 25/3: 23-44.

Martins, J. C. O. (2011), “Pensar Portugal - ironia, paródia e desencanto: Mário de Cavalho e o retrato melancólico de um país". In: Carvalho da Silva, J. A., Martins, J. C. O., Gonçalves, M. (eds.), Pensar a Literatura no Séc. XXI. Braga, Univ. Católica Portuguesa: 463-478.

Martins, J. C. O. (s.d.), "La barbarie de l'ignorance dans la culture postmoderne et la fiction de Mário de Carvalho". In: De l'Extrême: pratiques du contemporain dans les mondes ibériques et ibéro-américains, Paris, CRIMIC [em publicação].

Martins, M. F. (1983), Sombras e transparências da literature. Lisboa, INCM.

Martins, Maria João (2003), "Mário de Carvalho: crónica de um aturdimento" [entrevista], JL - Jornal de Letras, Artes e Ideias, no 864, 12 novembro, p. 12.

Mead, G. (1990), “The Representation of Fictional Character”. Style 24. 3: 440.

Medeiros, W. (1997), "Do desencanto à alegria: o Satyricon de Petrónio e o Satyricon de Fellini”. Humanitas 49: 169-175. 
Melanda, P. C. O. (2001), Pela mão de Clio. A reescrita da História em Mário de Carvalho. Aveiro. 38. Dissertação de Mestrado em Estudos Portugueses, apresentada à Universidade de Aveiro. Exemplar em CDRom.

Melero Bellido, A. (2001), "La utopia cómica o los límites de la democracia”, Cuadernos de Literatura Griega y Latina 3: 7-25.

Melero Bellido, A. (2004), "La lengua de la utopia". In: López Eire, A., Guerrera, A. R. (Eds.). Registros Lingüísticos en las lenguas clásicas. Salamanca, Ediciones Universidad Salamanca: 149-172.

Mendes, A. M. G. (1999), "Cultura clássica em Um Deus Passeando pela brisa da tarde de Mário de Carvalho”, III Colóquio Clássico - Actas, Aveiro: 347-363.

Mendes, A. M. G. (2005), “Trimalquião, os coronéis e a piscina: retrato impiedoso de um país em crise”. Ágora. Estudos Clássicos em Debate. Aveiro 7: 129-150.

Mendes, J. P. (1997), Construção e Arte das Bucólicas de Virgílio. Coimbra, Almedina.

Mendonça, F. (1997), “A Paixão do Conde Fróis”. Colóquio/Letras 99. Setembro-Outubro.

Mexia, P. (2005), “O Manuel Germano”. Diário de Notícias. Artes, 17 de Junho: http:// dn.sapo.pt/2005/06/17/artes/o_manuel_germano.html

Moisés, M. ('1973), A criação literária: introdução à Problemática da Literatura. São Paulo, Melhoramentos.

Mora, C. M. (2003), “A outra resposta de Tirésias”. In: Mora, C. M. (ed.), Sátira, Paródia e caricatura: da Antiguidade aos nossos dias. Aveiro, Universidade de Aveiro: 7-13.

Morais e Silva, A. (1953), Grande Dicionário da Lingua Portuguesa. Lisboa, Confluência.

Mourão, J. A. (1998), "Posfácio”, a Feijóo, Benito - Um Não Sei Quê. Lisboa, Vega.

Nickel, R. (1999), “Lucian's True Story: impressions of a fancy voyage”, Euphrosyne 27: 249-257.

Niederauer, S. (2008), "Era bom que trocássemos umas ideias sobre o assunto ou $\mathrm{O}$ simulacro da narrativa na pós-modernidade”. Letras de Hoje 43. 4: 83-88.

Oliveira, B. S. (1997), Eurípides. Hipólito. Brasília, Editora UNB.

Onelley, G. B. (2004), “A resistência da nau: cidade na luta pelo poder”. Calíope 12: 33-42.

Otte, G. (1996), "Rememoração e citação em Walter Benjamin". Revista de Estudos de Literatura 4. Belo Horizonte, Centro de Estudos Literários (CEL), Faculdade de Letras da UFMG: 211-223.

Pereira, E. (2003), "Viagens na minha terra: ciladas da representação". Revista do Centro de Estudos Portugueses 23 n. 32: 61-68.

Pereira, S. M. (2008), “Poética dos sonhos e das visōes em estado de vigília - I”, Humanitas 60: 11-28.

Pereira, S. M. (2009), "Poética dos sonhos e das visōes em estado de vigília - II”, Humanitas 61: 5-18.

Perelman, C. O. (1993), O Império Retórico: Retórica e Argumentação. Tradução de Fernando Trindade e Rui Alexandre Grácio. Porto, Ediçóes Asa. 
Perrin-Naffakh. A.-M. (1996), "Le langage cliché: aveu d'usure ou pouvoir d'écho". Confluências 14: 7-14.

Perrone-Moisés, L. (1979), “A intertextualidade crítica”. Poétique. Revista de teoria e análise literárias. Trad. port. Clara C. Rocha. Coimbra, Almedina: 209-230.

Pimentel, C. S. (2001), "O latim nas literaturas portuguesa e francesa: instrumentos, métodos e agentes de ensino”, Ágora, Estudos Clássicos em Debate 3: 183-185.

Piwnik, M.-H. (1998), "Mário de Carvalho: crónica de um desfecho anunciado", Veredas 1, Porto: 317-325.

Piwnik, M.-H. (2004), “De Sienkiewicz a Mário de Carvalho: Duas construções da História”. In: Literatura e História. Actas do Colóquio Internacional, Porto, vol. II: 139-144.

Platão ( $\left.{ }^{12} 2010\right)$, República. Trad. Maria Helena da Rocha Pereira. Lisboa, Fundação Calouste Gulbenkian.

Préchac, F. (1987), Sénèque. Lettres a Lucilius, II. Paris, Les Belles Lettres.

Queirós, E. de (s./d.), Os Maias. Lisboa, Livros do Brasil.

Queirós, E. de (2000), O Crime do Padre Amaro. Ed. crítica de Carlos Reis e M. Rosário Cunha. Lisboa, IN-CM.

Rabaté, E. (1996), "Henri Michaux et le cliché: résistance et fascination”. Confluências 14: 61-75.

Raimond, M. (1989), Le Roman. Paris, Armand Colin.

Reis, C. (1996), "Mário de Carvalho. Incitação ao romance”. Jornal de Letras 28 Agosto: 22-23.

Reis, C. (1997), "Fábula”. In: Biblos-Enciclopédia Verbo das Literaturas de Lingua Portuguesa. Lisboa, São Paulo, Verbo: 462-463.

Reis, C. (2005), História crítica da literatura portuguesa, vol. IX (Do neorrealismo ao postmodernismo). Lisboa, Verbo: 287-318.

Reis, C., Macário Lopes, A. C. (72007), Dicionário de narratologia. Coimbra, Almedina.

Ricoeur, P. (1983), Temps et Récit. T.I. Paris, Ed. du Seuil.

Rio Torto, G. M. (1996), "Linguagem e clichê", Confluências 14: 159-175.

Robilliard, M.-A. (2002), Água em pena de pato de Mário de Carvalho. Um teatro do desencanto. Trad. port. Manuel Ruas. Lisboa, Editorial Caminho.

Rocha Pereira, M. H. (1955), Concepçōes Helénicas de felicidade no além: de Homero a Platão. Coimbra, Maranus.

Rocha Pereira, M. H. (1980), Poesia Grega Arcaica. Coimbra, Instituto de Estudos Clássicos.

Rocha Pereira, M. H. (1984), Estudos de História da Cultura Clássica, vol. II (Cultura Romana). Lisboa, Fundação Calouste Gulbenkian.

Rocha Pereira, M. H. ('1994), Romana - Antologia da Cultura Latina. Coimbra, Universidade de Coimbra. 
Rocha Pereira, M. H. ( $\left.{ }^{10} 2006\right)$, História da Cultura Clássica, I (Cultura Grega). Lisboa, Fundação Calouste Gulbenkian.

Rodrigues, L. G. (2005), “A Radioestesia”. In http://rprecision.logspot.com/2005/06/radiestesia.html Rose, M. A. (1979), Parody and meta-fiction. London, Croom Helm.

Sant'Anna, A. R. ('1985), Parodia, paráfrase \& cia. São Paulo, Ática.

Santos, R. B. (2009), Aspectos da Herança Clássica em Mário de Carvalho. Belo Horizonte, Faculdade de Letras da UFMG, 2009. [versão policopiada].

Saramago, J. (1989), História do Cerco de Lisboa. Lisboa, Caminho.

Saramago, J. (1990), "História e Ficção”. Jornal de Letras, Artes e Ideias, 6 de Março.

Schaeffer, J. M. (1992), L'art de l'àge moderne. L'esthétique et la philosophie de l'art du XVIIIème siècle à nos jours. Paris, Gallimard.

Schmidt, W. (1963), Der Deus Ex Machina bei Euripides. Tübingen University.

Schwartz, J. (1981), Murilo Rubião: A poética do Uroboro. São Paulo, Editora Ática.

Scodel, R. (1999), Credible impossibilities. Conventions and strategies of verisimilitude in Homer and Greek tragedy. University of Michigan Press.

Sedlmayer, S., "Sinais de fogo, aviso de incêndio: ideias estéticas, históricas e literárias em Jorge de Sena e Walter Benjamin”. In: Revista Literatrua e Autoritarismo. Dossiê Walter Benjamin e a Literatura brasileira. Santa Maria, Universidade Federal de Santa Maria/ RS. Disponível em http://w3.ufsm.br/grpesqla/revista/dossie05/art_02.php

Seel, M. (1992), "Le langage de l'art est muet". In: Bouchindhomme, Ch., Rochlitz, R. (eds.), L'art Sans Compas. Redéfinitions de l'Esthétique. Paris, Éd. du Cerf.

Segurado e Campos, J. A. (1991), Cartas a Lucílio, Lisboa, Fundação Calouste Gulbenkian.

Seixo, M. A. (1995), "Mário de Carvalho. Romance, Humanismo e BD”, JL - Jornal de Letras, Artes e Ideias, 12. 4: 24-25.

Sena, J. http://www.letras.ufrj.br/lerjorgedesena/port/antologia/ficcao-e-teatro/texto.php?id=319

Sequeira, M. G. R. (1996), Aproximação a uma Leitura do Risivel em A Paixão do Conde de Fróis. Tese de Mestrado apresentada à Faculdade de Letras da Universidade do Porto (dact.).

Settis, S. (2006), El futuro de lo 'clásico'. Traducción de Andrés Soria Olmedo. Madrid, Abada Editores.

Silva, M. F. (1987), Critica do teatro na comédia antiga. Coimbra, INIC.

Silva, M. F. (2005), Ensaios sobre Euripides. Lisboa, Cotovia.

Silva, M. F. (2007), "A porta na comédia de Aristófanes: uma entrada para a utopia”. In: Ensaios sobre Aristófanes. Lisboa, Cotovia: 257-274. 
Silva, M. F. (2008), "Mensagens, cartas e livros no teatro grego antigo", in Matos, M. C. (ed.), Helénicos. Estudos em homenagem do Prof. Jean-Pierre Vernant (1914-2007). Lisboa, Ediçôes Távola Redonda: 227-260.

Silva, M. F. (2009), Utopias e distopias. Coimbra, Imprensa da Universidade.

Silvestre, O. M. (1998), "Mário de Carvalho: Revolução e Contra-revolução ou um passo atrás e dois à frente”. Colóquio/Letras 147/148: 209-229.

Silvestre, O. e Diogo, A. L. (1998), "Entrevista a Mário de Carvalho", in <http://www. ciberkiosk.pt>, arquivo, $\mathrm{n}^{\circ} 1$ (15 pp.).

Simões, M. J. (2006), “Atrevidas e desbordantes: as personagens em Mário de Carvalho”. In Figuras da Fiç̧ão. Coimbra, Centro de Literatura Portuguesa: 79-92.

Spivak, G. Ch. ('2003), “Can the subaltern speak?” In: Asheroft, B., Griffith, G., Tiffin, H. (eds.), The post-colonial studies reader. New York, Routledge.

Spivak, G. Ch. (1998), "Puede hablar elsujeto subalterno?”. Orbis Tertius 3. 6: 1-44.

Sterne, L. (1860), The Works of Lawrence Sterne. London, Henry Bohn.

Thomasson, A. (2003), "Fictional Characters and Literary Practices". British Journal of Aesthetics 43. 2, April:138-157.

Todorov, T. (1999), O homem desenraizado. Trad. Christina Cabo. Rio de Janeiro, Record.

Torrão, J. M. N. (ed.) (1999), III Colóquio Clássico. Aveiro, Universidade de Aveiro.

Tosi, R. (2000), Dizionario delle sentenze latine e greche. Milano, Biblioteca Universale Rizzoli.

Trindade, L. (2004), “Os excessos de Abril”, História 65: 20-31.

Valente, A. M. (2004), Aristóteles. Poética. Lisboa, Gulbenkian.

Várzeas, M. (2001), Silêncios no teatro de Sófocles, Lisboa, Cosmos.

Villeneuve, F. (1970), Horace. Odes et Epodes, I. Paris, Les Belles Lettres.

Xavier, L. G. (2007), O discurso da ironia. Lisboa, Novo Imbondeiro.

Walton, K. (1990), Mimesis as Make-Believe: On the Foundations of the Representational Arts. Cambridge Mass., Havard University Press.

Waugh, P. (2003), Metafiction. The Theory and Practice of Self-Conscious Fiction. London \& New York, Routledge [1984].

Wesseling, E. (1991), Writing History as a Prophet. Postmodernist Innovations of the Historical Novel. Amsterdam/Philadelphia, John Benjamins.

Wolff, F. (2004), “Quem é bárbaro?”. In: Novaes, A. (ed.), Civilização e Bárbarie. São Paulo, Companhia das Letras: 19-43.

Woods, J. (1974), The Logic of Fiction. Paris, Mouton; (2010), A Mecânica da fiç̧âo. Lisboa: Quetzal. Zagajewski, A. (2003), En la belleza ajena, trad. esp. A. E. Diaz-Pintado Hilario, Valencia, Pre-Textos. 